\title{
THE RELIGIOUS CONVERSION PROCESS AS AN UNUSUAL LIFE EXPERIENCE TO THE MALAYSIAN CHINESE MUSLIM CONVERTS IN THE CONTEXT OF ADULTHOOD SELF-DIFFERENTIATION DEVELOPMENT
}

\author{
Loo Tuck Yee ${ }^{1}$ \\ Universiti Utara Malaysia. \\ (Email: tyloo73@gmail.com) \\ Nadiyah Binti Elias ${ }^{2}$ \\ Universiti Utara Malaysia. \\ (Email: nadiyah@uum.edu.my) \\ Mariny Abdul Ghani ${ }^{3}$ \\ Universiti Utara Malaysia. \\ (Email: mariny@uum.edu.my)
}

Received date: $21-08-2019$

Revised date: $27-08-2019$

Accepted date: 27-08-2019

Published date: 15-09-2019

To cite this document: Loo, T. Y., Elias, N., \& Abdul Ghani, M. (2019). The Religious Conversion Porocess As An Unusual Life Experience to The Malaysian Chinese Muslim Converts in The Context of Adulthood Self-Differentiation Development. International Journal of Education, Psychology and Counseling, 4 (32), 164-173.

DOI: $10.35631 /$ IJEPC.4320016

\begin{abstract}
This study explores the role of religious conversion as an unusual life experience in facilitating adulthood self-differentiation development in the context of Malaysia Chinese Muslim converts. It is a qualitative phenomenology study, five participants from the northern religion of Malaysia were taking part, and data were collected by semi-structured interviews. This study has identified the religious conversion has placed the Chinese Muslim converts in the hardships of (a) marginalized minority, (b) deviation and (c) association status which might facilitate self-differentiation development.
\end{abstract}

Keywords: Adulthood Self-differentiation Development, Religious Conversion Process, Malaysia Chinese Muslim Converts. Qualitative Study

\section{Introduction}

Self-differentiation level is referred to as the ability to separate from family of origin emotionally and physically (Charles, 2001). It consists of intrapsychic and interpersonal aspects (Bitter, 2009; Bowen, 1978; Goldenberg \& Goldenberg, 2004). Intrapsychic is referred to the ability to separate individuals' feeling and thinking system, and interpersonal is referred to the ability to experience intimacy with others but still function as autonomous individuals. Selfdifferentiation level is fixed after reaching adulthood. However, exposure to unusual life 
experience, structural effort and learning process might facilitate adulthood self-differentiation development (Kerr \& Bowen, 1988).

The term conversion originated from Hebrew, Greek and Latin. It brings the meaning of turn, to turn and turn again (Paloutzian, Richardson, \& Rambo, 1999). The central theme of religious conversion is "change" (Bockian, Glenwick, \& Bernstein, 2005; Hester, 1998; Paloutzian et al., 1999). It is to correct the wrongdoings before the conversion ((Vokes, 2007). It referred to as changing ones' belief system to another (Jindra, 2008), or spiritual disposition (Smith \& Stewart, 2011). It is the result of modernisation toward rational thought and religious action (Woods, 2012; Yang, 1998).

This study takes adulthood self-differentiation development and religious conversion as the study topics because both aspects have the same themes, which are changes and maturity. Both processes involve much of the individuals' learning process and effort taking to become a better self-being.

\section{Adulthood Self-Differentiation Development and Religious Conversion}

Based on previous studies and literature, adulthood self-differentiation development could happen. Roytburd \& Friedlander (2008) has found out that the longer time the Jewish Refugees stay in the United States; the more self-differentiated they will be. Griffin \& Apostal (1993) and Vancea (2013) experimental studies have proved that the self-differentiation level could change through psychotherapy training. Issenmann (2008) also found out that studying aboard significantly influenced individuals' self-differentiation level. Besides, Davis (2011) also mentioned adulthood self-differentiation development might also be achieved by monitoring the family role and family emotional process.

Previous studies and literature have proved that religious conversion is an unusual life experience. Studies had shown that it is a complex (Ozyurek, 2018) hostility (Iyadurai, 2010), loneliness and isolated (Jensen, 2008; Larson, 1996) human experience. This unusual life experience is significant to the Chinese Muslim converts because studies have shown that they are treated as betrayals to compatriot community (Lam, 2005). Malay Muslim community consider they are not pure Muslims (Jacobsen, 2005); meanwhile, the Chinese community will consider they have becoming Malays (Ma, 2005). Studies have shown that they are boycotted (Ali Muhamud, 2007), rejected (Mohd Ridhuan Tee Abdullah, 2009) and suspected (Ma, 2005). Furthermore, Muslim converts are treated as contradicting with modern values (Jensen, 2008; Yip, 2008).

From the above discussion, adulthood self-differentiation could be developed, and religious conversion is an unusual human experience. This study intends to explore the role of religious conversion in developing adulthood self-differentiation in the context of unusual life experience and the Malaysian Chinese Muslim converts.

\section{Methodology}

This is a qualitative study focuses on the participants' experiences and transformed their meaningful, relevant experiences into consciousness (King \& Harrocks, 2010; Mason, 1996; Merriam, 2009). The researcher used the semi-structured interviews in collecting primary data, which allowed the participants to respond according to their perspectives, feelings and behaviours (Merriam, 2009) but still in the range of study scope. The interview protocol was modified from the religious conversion protocol used in Lam's study (2005). 
There were three males and two females, Chinese Muslim converts participated in this study. The sampling method was the snowball method. All participants ere converted after 18 years old and at least 10 years of conversion experience. There were 19 interview sessions, 34 interview hours had been conducted. To protect the participants' privacy,all names used in the study were not their real name.

This study used Braun and Clarke (2006) model as guidance to analyse the collected data. The stages of analysis are the (a) transcription, (b) generating initial codes, (c) searching themes across transcripts, (d) reviewing themes, (e) naming and refining themes, and (f) producing the final result. ATLAS.ti 8.2 was used in data analysis.

\section{Findings}

Most studies had defined converts as a deviant group (Lee, 2008). The researcher defines religious conversion as an unusual life experience because it exposes converts to extraordinary experiences that most people are not experienced. This study has identified the religious conversion has (a) shifted the Chinese Muslim converts from a majority group to be the minority group, (b) deviated them from parental and societal mainstream values and (c) associated them with new values and norm.

\section{Shifted arom A Majority Group To Be In The Minority Group}

Islamic conversion is an unusual life experience to the Malaysian Chinese Muslim converts because they are shifted from a majority group to the minority group. Religious conversion has placed Chinese Muslim converts in a double minority position (Chen, 2010). Only about $1 \%$ of the population in Malaysia are Chinese Muslims (Wan Kamal Mujani, Abdul Qayyum Abdul Razak, Allawati Kasri, Mohd Irman Mohd Abd Nasir, \& Noor Inayah Ya'akub, 2012), and the official statistic population is about 42,000 (Department of Statistics, 2011). Chinese Muslims are facing tremendous pressure to assimilate into mainstream society because of their religion and cultural identity (Frankel, 2008). Converts are the marginalised group which are humiliated by the majorities (LaMothe, 2011)

Based on the interview besides Khairul Wong's mother had the intention to covert, and Hafiz Lim's three cater-cousins were converted, none of the participants' family member has converted to Islam.

"My mother had accepted my religion. I ask her if she feels that Islam is good, why not she converts to Islam. She said she wanted to invite my sister to convert together. She wanted my whole family to convert to Islam. Finally, they made the decision not to convert." (Khairul Wong)

\section{"I have two nieces, and one of my cousins have converted to Islam." (Hafiz Lim)}

The religious conversion has shifted the Malaysia Chinese Muslim converts to be a minority group. They are shifted from Chinese to be the minority Malaysia Chinese Muslim converts. They learn and taking effort to live as a minority in the mainstream majority community.

\section{Deviated from The Parental and Compatriot Value}

Chinese who are converted to Islam are always treated as betrayals to their ethnic (Lam, 2005). Instead of religious conversion, it is more to ethno-apostasy (Phillips \& Kelner, 2006). They are treated as "not Chinese" and boycotted (Ali Muhamud, 2007) to become a marginal minority group in their own compatriot community (Bo, 2003). 


\section{Deviated from Parental and Compatriot Religion}

Chinese traditional religion is the mainstream among the Malaysian Chinese (Tan, 2003; Tan, 1983). All the participants practised Chinese traditional religions before converting to Islam. They are deviated from the compatriot mainstream religious practices and have a unique experience to deal with the deviation.

Khairul Wong had an extreme resistance from his family, especially on the ritual issue. Azman Low had to draw a clear cut with his compatriot and family on religious practices.

"My relatives wanted me to pray their God. I refused. They made noise. Why this is the last pray for your grandfather, but you still refuse to do for him? They said nobody would know. This is your grandfather final time why you cannot pray. I said why I need to pray." (Khairul Wong).

"After coming back to Malaysia, my parents stayed with me for a while. I did not allow them to pray in my house. I allowed my mother to place an image. It is prohibited, but I respect her. She had not burned any joss stick. She only recited the scriptures." (Azman Low)

Jamilah Ang is inclusive of her religious practices. She accepts but not involved in compatriot religious practices.

"I went back to attend the ritual. My mother called me to go back. We can go back to see the ritual. We can help in preparing the ritual...but we could not participate in the ritual." (Jamilah Ang)

Khairul Wong, Azman Low and Jamilah Ang deviate from their parents and compatriot religion. They have separated religious identity with them. They are Muslim now; their family members are not. Their life is different from their family members. They have to learn and take effort to stay comfy in the religious deviation

\section{Deviated to Family and Compatriot Norm}

Once a Chinese converted to Islam, they deviate from family and compatriot norm. The Chinese espouse Chinese value and culture (Ying, Coombs, \& Lee, 1999). They have resistance to accept both Islam religion and Chinese Muslim converts because they are very proud of their culture (Mohd Ridhuan Tee Abdullah, 2009). Chinese Muslim are treated as degraded (Ali Muhamud, 2007; Ma, 2005) and contradicted with modern values (Jacobsen, 2005; Jensen, 2006; Yip, 2008). They might suddenly become orphans and isolated from their family and compatriot after converting. Some of them even force to break up their long term family relationship.

When Nurul Tan expressed her desire to embrace Islam, she had to leave her family because they could not accept her Muslim identity, especially the father. She came back to her family ten years after embracing Islam. Khairul Wong had to move out from his mother house after coming out as a Muslim. Besides family, Jamilah Ang was also boycotted by some of her peers. They refused to sit together with her in the canteen when taking food.

"My family asked me. I replied I want to convert Islam. They did not agree. They wanted me to think about it... I told them I wanted to convert. They did not agree. I had no way as I already made my decision. I had no way to turn. Finally, I converted ... Ten years, I never speak to my father, even one word. I only spoke to my mother on the phone. It was already ten years." (Nurul Tan) 
"I had a few Chinese friends; they did not want to make friend with me. They were not understood. Islam is Islam; Malays are Malays. They are different. They boycotted me. They did not want to make friend with me. They refused to take food on the same table with me in a canteen.". (Jamilah Ang)

Self-deviated is another issue. Some converts could not really accept their own Muslim identity. When Nurul Tan interacted with peers, she feels not comfortable. She cares about how people treat her as a Muslim.

"There are still a few old friends who still cannot accept me. Frankly speaking, not everybody can accept. My worried.... Not everybody can accept, you know. I can go to the ceremony. I scared of how they look at me. The ways they look at you are very odd. They look at you from head to toe. You are Chinese, but you are not Chinese. Am I looked so wired? ... They invite me to go to the gathering. I can go, but you have any problem or not?.... This is because they bring their friends together. I am afraid their friends have a problem with me. I do not want they feel not comfortable about me. Suddenly come out with a scarf lady. I do not want this to happen." (Nurul Tan)

The norm deviation has created a unique experience to converts. They might be treated as nonChinese. They have to learn and take effort to stay in the deviation as a Chinese, as a member of the family and compatriot member.

\section{Associates Into A New Norm}

After converting to Islam, Chinese Muslim will take action to associate into a new norm. They might take action to assimilate into the mainstream Malay Muslim community and integrate into compatriot Chinese community. Unless they internalised Malay Muslim living habits, they are considered as new Muslim brothers (saudara baru) and not entirely accepted (Lam, 2005). They have different ethnic background (Jacobsen, 2005). Meanwhile, when they want to integrate into Chinese community no matter how they present their Chinese characteristics, they have changed their living habits, such as Islamic name, which is more 'Malay' (Hew, 2004). They might not readily be accepted. Converts are treated as the wrong kind of Muslim and bizarre human being (Jensen, 2008, p.401). They are always considered to be "others" in the religious and compatriot community. They come out with minority identity to assimilate into the mainstream religious and compatriot community.

\section{Associate To The Mainstream Malays Muslim Community}

When the Chinese Muslims associate themselves into the mainstream Muslim community, they could feel the suspicious (Lam, 2005). They felt that the Malay Muslims distrust about their behaviours, motives and sincerity. Hafiz Lim stayed in a mosque in order to bring himself closer to the religion, but Muslims came to the mosque to peep at him. They wanted to know if he still had any wrongdoing after converting.

"I stayed in the mosque for forty days.... Malay people treated me differently. They suspect I was mafia. They suspect I was drug-addicted. When I was sleeping, they came to peep at me. A lot of them peeped at me when I was taking my bath. They suspected I was drug abused. They started to hate me." (Hafiz Lim)

Jamilah Ang worked very hard to remove the suspicious. When she was just converted to Islam, she dared not get too close to the Chinese.

"There we some Malays Muslims not believed me. They suspected about my faith. They thought I was playing with the religion. I was not sincere to Islam. They beware of me...I 
stayed here; I followed Islam. I never followed the Chinese...I wore clothes that covered up my aurat. I only bought food from Malay stall. I never take food from the Chinese stall." (Jamilah Ang)

The association into the mainstream Malays Muslim community has placed the Chinese Muslim in hardship and difficulties. They are different from the mainstream Muslim in term of cultural and ethnic background. They learn and take effort to assimilate into the mainstream Malays Muslim community.

\section{Associate Into The Mainstream Chinese Compatriot Community}

Chinese converts even have more dilemma relationship when they associate with the mainstream compatriot Chinese community (Mohd Ridhuan Tee Abdullah, 2009). They have to keep their distance from the community. Hafiz Lim did not feel comfortable to mix around with his Chinese friends. His Chinese friends did not accept his conversion. They began to alienate and distance from him.

"At the initial stage, I felt ashamed if I met Chinese.... They asked me why you want to do such things. Why wear white skull? Why you circumcised? Why you keep the beard? You do it to please the Malays ... My friends do not like the Malays. We need to circumcise. It is troublesome ... I was entirely alienated. I changed a few batches of friends. I started to find Malay friends. I know it was very hard to find Chinese friends. They could not accept me." (Hafiz Lim)

Azman Low entirely kept a distance from his compatriot community purposely. The distance came from his rejection and criticism of his traditional compatriot practices.

"Do you mean non-Muslim friends or non-Muslim relatives? I seldom get in touch with them. Most of the people I am getting touch are Muslims ...I only connect to the Chinese when I go to the market...I seldom mix up with them ... Traditional 's practices, they pray everything. They pray in the seventh month. They pray on the ninth month. They pray for everything. It is over. They pray too much. They are perverted." (Azman Low)

When the Chinese Muslim converts go back to the mainstream compatriot community, they are not treated as Chinese. They are being humiliated and not accepted. The integration process into the mainstream compatriot Chinese community involved a lot of learning and effort taking.

\section{Discussion}

In the Western context, religious conversion is merely a personal choice. This is the reason Holmes \& Rahe (1967) in The Holmes-Rahe Life Stress Inventory does not include religious conversion. However, from the Chinese collectivistic context, religious conversion is considered as an unusual life experience. It places the Chinese Muslim converts into the minority, marginalised, deviation and association status. The researcher suggests that religious conversion or specifically Islamic conversion could be ranked as one of the most stressful challenges in the Chinese collectivism context, even higher than the death of a spouse.

Religious conversion is considered as an unusual life experience to the Malaysian Chinese Muslim converts (Lam, 2005; Ma, 2005; Ozyurek, 2018). The researcher further explores the experience in the context of the Malaysian Chinese Muslim converts. Religious conversion has exposed the converts to the difficulties and challenges of marginalised, deviation and association. It pushes the converts into the learning and effort taking status to be intrapsychic 
self-differentiated as a Muslim and a Chinese, and interpersonal self-differentiated to live comfy in the mainstream religious and compatriot community.

Bowen did not explain how the self-differentiation develops in adulthood. Studies have proved that self-differentiation development could happen in psychological training (Griffin \& Apostal, 1993) and psychological therapy (Vancea, 2013). The researcher suggests that selfdifferentiation development is attached parallel with another growing process in the context of unusual life experience. In this study, it is the religious conversion process. The marginalised, deviation and association experiences attract the learning process and effort taking to overcome the hardships and challenges to move toward adulthood self-differentiation development.

Bowen suggests that adulthood self-differentiation development could be achieved by unusual life experience, learning process and structural effort (Kerr \& Bowen, 1988). Although previous studies had proved that migration (Roytburd \& Friedlander, 2008) and study aboard (Issenmann, 2008) might affect individual self-differentiation level. However, the researcher suggests that unusual experience only as a setting which attracts learning process and effort taking. It provides the elements of hardships, difficulties, anxieties, stresses and struggles. Once converts are willing to take the challenges to deal with those hardships, it invites the learning process and effort taking of being more self-differentiated, maturity, adaptable, flexible and reflective to the religious conversion environment.

\section{Conclusion}

Instead of generalisation, this study tends to offer preliminary exploration for further study comparatively. Since this study only involves a small number of participants. The findings could not extend to the broader population. A future study that involves a larger number of the population is needed to give an overall explanation of the phenomena.

To enhance the credibility of this study, the researcher suggests a more significant number and diversity of participants replicate the study. Future studies might consider diversity but not limited to genders, religious conversion experiences, original origins, education levels and ages. To consolidate the assumption of self-differentiation development in adulthood in the context of unusual life experience, the researcher suggests extending more studies to other life change stressful events, such as severe sickness, death of a spouse, study abroad, divorce, and migration.

This study has found out that the religious conversion process fulfilled Bowen adulthood selfdifferentiation development condition. The (a) marginalized minority status, (b) deviation from parental and compatriot values and (c) association to new norm processes have place the Malaysia Chinese Muslim converts into an unusual life experience. They learn and take effort to deal with the hardship and difficulties to be more self-differentiated in order to be comfy in the religious conversion process.

\section{References}

Ali Muhamud. (2007). Chinese Muslims in colonial and postcolonial Indonesia. Islam in Southeast Asia, 7(2), 1-22. Retrieved from http://www.hawaii.edu/cseas/pubs/explore/download/v7n2/UHM.Explorations.v7n2.A li.pdf

Bitter, J. R. (2009). Theory and practice of family therapy and counseling. CA: Brooks/ Cole. 
Bo, C. (2003). A multicultural interpretation of an ethnic Muslim minority: The case of the Hui Tibetan in Lhasa. Journal of Muslim Minority Affairs, 23(1), 41-61. https://doi.org/10.1080/1360200032000072996

Bowen, M. (1978). Family therapy in clinical practice. New Yoke: J.Aronson.

Braun, V., \& Clarke, V. (2006). Using thematic analysis in psychology. Qualitative Research in Psychology, 3(2), 77-101. Retrieved from http://www.tandfonline.com/doi/abs/10.1191/1478088706qp063oa

Charles, R. (2001). Is there any empirical support for Bowen's concepts of differentiation of self , triangulation , and fusion? The American Journal of Family Therapy, 29, 279292.

Chen, J. X. (2010). Malaysia Chinese Muslim series 1: Dilemma (In Chinese). Nanyang Shang Pao.

Chung, H., \& Gale, J. (2006). Comparing self-differentiation and psychological well-being between Korean and European American students. Contemporary Family Therapy, 28, 367-381. https://doi.org/10.1007/s10591-006-9013-z

Davis, D. M. (2011). Relations among meditation experience, mindfulness, differentiation of self, and countertransference management. Available from ProQuest Dissertations and Theses database (UMI No. 3483696). Retrieved from https://etda.libraries.psu.edu/paper/11671/6492

Department of Statistics, M. (2011). Population distribution and basic demographic characteristics 2010. Kuala Lumpur.

Frankel, J. D. (2008). "Apoliticization": One facet of Chinese Islam. Journal of Muslim Minority Affairs, 28(3), 421-434. https://doi.org/10.1080/13602000802548078

Goldenberg, I., \& Goldenberg, H. (2004). Family therapy, an overview (6th ed.). CA: Thomson Learning. Icl.

Griffin, J. M., \& Apostal, R. A. (1993). The influence of relationship enhancement training on differentiation of self. Journal of Marital and Family Therapy, 19, 267-272.

Hew, W. W. (2004). Penamaan dan identiti Cina Muslim: Pensempadanan, perundingan dan kacukan identiti di Malaysia. 4th International Malaysian Studies Conference; 3-5. Paper presented at International Malaysia Studies Conference, Universiti Kebangsaan Malaysia, Bangi. Retrieved from http://english.cpiasia.net/dmdocuments/Chinese Muslim Identities_Debating Cultural Creolization in Malaysia.pdf

Issenmann, A. (2008). An examination of the impact of studying abroad with AFS on level of differentiation. (Doctoral's thesis), Virginia Polytechnic Institute and State University, Blacksburg. Retrieved from http://scholar.lib.vt.edu/theses/available/etd-10082008$172721 /$

Iyadurai, J. (2010). The Step Model of transformative religious experiences: A phenomenological understanding of religious conversions in India. Pastoral Psychology, 60(4), 505-521. https://doi.org/10.1007/s11089-010-0287-6

Jacobsen, M. (2005). Islam and processes of minorisation among ethnic Chinese in Indonesia: Oscillating between faith and political economic expediency. Asian Ethnicity, 6(2), 7187. https://doi.org/10.1080/14631360500135096

Jankowski, P. J., \& Sandage, S. J. (2011). Meditative prayer, hope, adult attachment, and forgiveness: A proposed model. Psychology of Religion and Spirituality, 3(2), 115-131. https://doi.org/10.1037/a0021601

Jensen, G. T. (2008). To be 'Danish', becoming 'Muslim': Contestations of national identity? Journal of Ethnic and Migration Studies, 34(3), 389-409. https://doi.org/10.1080/13691830701880210 
Jensen, T. G. (2006). Religious authority and autonomy intertwined: The case of converts to Islam in Denmark. The Muslim World, 96(4), 643-660. https://doi.org/10.1111/j.14781913.2006.00151.x

Jindra, I. W. (2008). Religious stage development among converts to different religious groups. International Journal for the Psychology of Religion, 18(3), 195-215. https://doi.org/10.1080/10508610802115768

Kerr, M. E., \& Bowen, M. (1988). Family evaluation: An approach base on Bowen theory. New York: Norton \& Company.

King, N., \& Harrocks, C. (2010). Interviews in qualitative research. Singapore: SAGE Publications Asia-Pacific Pte Ltd.

Lam, J. Y. Y. (2005). Religion conversion and reconstruction of identities: The case of Chinese Muslim converts in Malaysia. National University of Singapore, Singapore.

LaMothe, R. W. (2011). Political humiliation and conversion. Pastoral Psychology, 60, 537549. https://doi.org/10.1007/s11089-010-0303-X

Larson, W. F. (1996). Critical contextualization and Muslim conversion. International Journal of Frontier Missions, 13(4), 189-191.

Ma, R. (2005). Shifting identities: Chinese Muslims in Malaysia. Asian Ethnicity, 34(2), 89107. https://doi.org/10.1080/14631360500135146

Mason, J. (1996). Qualitative Researching. London: SAGE Publication. Inc.

Merriam, S. B. (2009). Qualitative research: A guide to design and implementation. San Francisco: Jossey-Bass.

Mohd Ridhuan Tee Abdullah. (2009). Persepsi orang Cina terhadap Islam Hadhari. Jurnal Hadhari, 1, 77-98.

Ozyurek, E. (2018). A Review of Lewis R. Rambo and Charles E. Farhadian's The Oxford Handbook of Religious Conversion. Pastoral Psychology, 67(2), 215-217. https://doi.org/10.1007/s11089-016-0714-4

Paloutzian, R. F., Richardson, J. T., \& Rambo, L. R. (1999). Religious conversion and personality change. Journal of Personality, 67(6), 1047-1079. Retrieved from http://onlinelibrary.wiley.com/doi/10.1111/1467-6494.00082/abstract

Phillips, B., \& Kelner, S. (2006). Reconceptualizing religious change: ethno-apostasy and change in religion among American Jews. Sociology of Religion, 67(4), 507-524. Retrieved from http://socrel.oxfordjournals.org/content/67/4/507.short

Roytburd, L., \& Friedlander, M. L. (2008). Predictors of Soviet Jewish refugees' acculturation: differentiation of self and acculturative stress. Cultural Diversity \& Ethnic Minority Psychology, 14(1), 67-74. https://doi.org/10.1037/1099-9809.14.1.67

Sandage, S. J., \& Jankowski, P. J. (2010). Forgiveness, spiritual instability, mental health symptoms, and well-being: Mediator effects of differentiation of self. Psychology of Religion and Spirituality, 2(3), 168-180. https://doi.org/10.1037/a0019124

Skowron, E. a., Stanley, K. L., \& Shapiro, M. D. (2009). A Longitudinal perspective on differentiation of self, interpersonal and psychological well-being in aoung Adulthood. Contemporary Family Therapy, 31, 3-18. https://doi.org/10.1007/s10591-008-9075-1

Smith, A. C. T., \& Stewart, B. (2011). Becoming believers: Studying the conversion process from Within. Zygon, 46(4), 806-834. https://doi.org/10.1111/j.14679744.2011.01226.x

Tan, C.-B. (1983). Chinese religion in Malaysia : A general view. Asian Folklore Studies, 42(2), 217-252.

Tan, C.-B. (1991). A note on the Orang Yunnan in Terengganu. Archipel, 42, 93-120. https://doi.org/10.3406/arch.1991.2750

Tan, J. Y. (2003). Chinese Religions. New Catholic Encyclopedia, 2nd Edition, 3, 512-513. 
Vancea, F. (2013). The increase of the differentiation level of the self through unifying personal development. Procedia - Social and Behavioral Sciences, 78, 180-184. https://doi.org/10.1016/j.sbspro.2013.04.275

Vokes, R. (2007). Rethinking the anthropology of religious change: New perspectives on revitalization and conversion movements. Reviews in Anthropology, 36, 311-333. https://doi.org/10.1080/00938150701684201

Woods, O. (2012). The geographies of religious conversion. Progress in Human Geography, 36(4), 440-456. https://doi.org/10.1177/0309132511427951

Yang, F. (1998). Chinese conversion to evangelical Christianity: The importance of social and cultural contexts. Sociology of Religion, 59(3), 237-257. Retrieved from http://socrel.oxfordjournals.org/content/59/3/237.short

Ying, Y., Coombs, M., \& Lee, P. (1999). Family intergenerational relationship of Asian American adolescents. Cultural Diversity and Ethnic ..., 5(4), 350-363. Retrieved from http://psycnet.apa.org/journals/cdp/5/4/350/

Yip, H. W. (2008). Teaching Islam to educate multiethnic and multicultural literacy: Seeking alternative discourse and global pedagogies in Chinese context. Asian Ethnicity, 9(2), $77-95$. 